Waldemar Cisto

Cardinal Stefan Wyszyński University in Warsaw, Poland

\title{
The Historical and religious conditions of the split of Sudan in the context of Christian-Muslim relationships
}

\begin{abstract}
The split into the predominantly Muslim Northern Sudan, and Southern Sudan with a Christian and animist majority, had been emerging in the course of many centuries. Without any doubt, one is bound to mention the natural and geographical boundaries, the ethnical diversity of the regions, the influence exercised during the centuries by the Egyptians, Arabs and later on by the British. According to the opinions of some experts on the subject, there can be two distinct matters that have contributed to the split of the North and the South. These were education and religion. Apart from education, also the issue of religion was dividing the Sudan. After the declaration of independence on January 1, 1954 all the Christian private schools in the South were closed down. There remained only state schools with Arabic as the language of instruction and with the upbringing model based on the Koran teaching. Having obtained political independence, the fears of the British administration and Christian missionaries became a reality: Islam was made the state religion. The only way to attain an occupational and social status was to convert to Islam. Frequently, this took place according to the rule of an already accomplished fact or by pressure. In the context of Sudan, one of the biggest country in Africa, with its population of over 37 million, made up of 70 per cent Muslim believers , 14 per cent of Christians, and 12 per cent of animists, it is of great importance for the perception of fundamentalism to be familiar with the history of this country.
\end{abstract}

\section{Keywords}

South Sudan, North Sudan, Split of Sudan, Violations of human rights, Persecution of Christians, Islamisation. 


\section{Sudan}

Sudan is a country, which because of the armed conflict taking place there with its bloody character as well as its long endurance, has been present for many years in media reports. Living there alongside Christians, animists and Muslims make up a kind of "explosive mixture". The referendum concerning the split into Southern and Northern Sudan contributed to the fact that many people from the media and the political world took great interest in it, and it resulted in spreading the news about this seemingly unsolvable problem, that cost the lives of many millions of human beings. However, this split appears artificial and has its long history behind it.

In the context of Sudan, one of the biggest countries in Africa, with a population of over 37 million, composed of 70 per cent Muslim believers, 14 per cent of Christians, and 12 per cent of animists ${ }^{1}$, it is of great importance for the perception of fundamentalism to become familiar with the history of this country. The fundamentalist movement in Sudan has been present in Sudan since 1950s and was imported by students who accomplished their education in Egypt where they had encountered the ideas of the Muslim Brotherhood. In 1959-1964 this movement grew in strength. During the parliamentary elections in 1964 two of its representatives won seats in Parliament. Its formal representation was a Party called Islamic Charter Front. Sudanese fundamentalism like many other Muslim fundamentalisms is being termed "a return to the religion of ancestors".

\section{Origins of the formation of the two Sudans}

The split into the Northern Sudan, predominantly Muslim, and Southern Sudan with a Christian and animist majority, had been emerging in the course of many centuries. The literature on the subject mentions a couple of causes. Among them, without any doubt, are the natural and geographical boundaries, the ethnical diversity of the regions, and the influence exercised during the centuries by the Egyptians, Arabs and later on by the British. Nevertheless, regardless of the period of its history we talk about, one observes a visible consolidation and deepening of differences in it. The reason for the isolation of

\footnotetext{
W. Cisło, Raport Prześladowani i Zapomniani 2007-2008, Warszawa 2008, p. 140-145.
} 
the South of Sudan, also during the British-Egyptian rule at the turn of the $19^{\text {th }}$ century, was the natural obstacles such as, for instance, the Sudd marshes and the Nubian Mountains, both difficult to cross. What nature had created was in favour of more and more increasing ethnical variation between the South and the North. The North, for many centuries, was dominated by Hamitic peoples, who mixed very easily with the Arabs pressing down from Egypt since the $7^{\text {th }}$ century. The result is such, that today the majority of the Northern Sudan population is formed by Sudanese Arabs. In the South, on the other hand, the majority of the population is of the Nile-Hamitic and Nile group ${ }^{2}$. Economic interests turned out to be stronger than natural obstacles and already before the condominium era during the $19^{\text {th }}$ century the exploitation of the South had begun. The characteristics of the terrain were essential to the split, however, of much more importance were the various steps taken by the Egyptian, Arab and British ruling authorities.

The name Bilad al-Sudan meaning "the Land of Blacks", comes down from the Middle Ages and is ascribed to the Muslims, who used this term to describe the regions situated south of the Sahara Desert. The first references, regarding the region go back to the $4^{\text {th }}$ century B.C. and they confirm the close bonds with Egypt due to its geographical location. Up to the $1^{\text {st }}$ century A.D. there existed the provinces dependent on Egypt: Kush, Wa, Napata Kingdom, and enjoying a great deal of independence, the Kingdom of Meroe. The territory stretching out from the first to the fourth cataract of the Nile used to be known in Africa with the name of Kush and later on as Nubia. In the course of the $4^{\text {th }}$ century A.D., the Kingdom of Meroe was attacked and destroyed by the Christian state of Aksum from the regions of contemporary Ethiopia.

It is presumed that the entire territory now called Northern Sudan, was subject to the process of islamisation by Arabic peoples. The territory of Northern Sudan requires still more extensive research and archeological work in order to prove traces of the Christian presence during the first centuries of the existence of this religion.

Islamisation processes took place incidentally during the migration of Arabic tribes from the Arabian Peninsula and Upper Egypt. Those processes were encouraged by the fact, that the Church did not acquire any enduring status within the local culture. It was rather associated with something alien, coming

2 See M. Ząbek, Zróżnicowanie etniczne, in: Róg Afryki. Historia i wspótczesność, ed. J. Mantel - Niećko, M. Ząbek, Warszawa 1999, p. 49-55. 
from a foreign culture, though officially tolerated. The fact proving some kind of superficiality in the acceptance of Christianity was the maintaining of some pre-Christian religious practices. One factor in this difficulty was the process of inculturation, and the acceptance of Christianity, and also the fact that Sudan did not develop its own indigenous church hierarchy. The majority of the clergy stemmed from Egypt. Nevertheless, during the years of prosperity such pilgrim venues, as for instance, Banganarti, were widely known in the world of that time. Arab interest in those regions was caused mainly by economic reasons. The steady growth in the population in the region enhanced the need to look for better conditions for their livestock. The next stage of their presence was the special districts in the Christian towns. Another stage in strengthening their presence was mixed marriages. The result of these factors was a common use of the Arabic language, though it is likely that it was a much more liberal form of Islam than those we are familiar with today. In the Funj Kingdom (1504 - 1821), extending from Kurdufan to the $3^{\text {rd }}$ cataract, there emerged something that can be called a flourishing of Sudanese culture ${ }^{3}$. Today's views, commonly accepted, classify Sudan as one of the most islamized countries in Africa. It is more difficult for many to come to the truth, so strongly supported by history, that this country contains in itself an almost one-thousand-year-long presence of Christianity. Across the Sudan, runs the southernmost boundary of Christianity in the region of the Nile Delta, which Christian presence was established in the middle of the $6^{\text {th }}$ century and lasted for a couple of centuries. The distinct confirmation of this fact is the result of archeological excavations presently underway with the great contribution of Polish scholars ${ }^{4}$. Three medieval kingdoms: Nobadia, Makuria and Alodia, occupying the area extending between the $1^{\text {st }}$ cataract and the Blue Nile Basin, were christianized thanks to the missionaries sent from Byzantium $^{5}$. We should not forget also about the influence from neighbouring Egypt where Christianity was at its greatest blossom. Egypt, as the cradle of monastic life, conveyed the value of Christianity to its neighbours. Prevailing conditions in the Nubia of that time were almost ideal for the development of

3 See G. Vantini, Oriental Sources concerning Nubia, Bologna 1975, p. 8-23.

4 See Ali Elmirghani Ahmed, Mariusz Drzewiecki, Piotr Maliński, Polsko-sudański projekt naukowy „Fortece Sudanu”. Krajobrazy kulturowe w perspektywie badań archeologicznych i etnologicznych, in: Sudan - bogactwo kultur i wewnętrzne napięcia, ed. W. Cisło, J. Różański, M. Ząbek, Warszawa, 2012, p. 51-82.

5 See G. Vantini, Oriental Sources concerning Nubia, Bologna 1975, p. 8-23. 
monastic life. There is no information about the original literature written by the monasteries in the Nubia. Those surviving to these days came from the descriptions by Arabic explorers and historians ${ }^{6}$.

During this period of the history of Sudan, it is worth highlighting one very interesting fact. In Darfur (nowadays the western part of Sudan) in the $16^{\text {th }}$ century there arose the kingdom of Keira where the population was Islamic, but it did not surrender to the process of arabization.

The next period in the history of Sudan is under the Turco-Egyptian rule, featured in the literature of the subject under the name Turkiyah. This period lasted from 1821 till 1881. This situation was influenced also by the fact, that Egypt was conquered by the Ottoman Empire and ruled by Muhammad Ali Pasha. This ruler raided Sudan territory in 1820. His sons got engaged in the exploitation of Sudan as a location for the best quality of slaves. This period brought about certain events which began to affect the minds of the Sudanese people. One of these elements was that slaves were found mainly in the southern region of Sudan, populated inter alia by the Dinka tribe, whose members were very tall and strong, people that in an obvious way made slave traders show greater interest in this region. What created animosities, lasting to the present day, was the fact that the slave trade was not just the business of the Egyptians, but also of some of the Sudanese kingdoms such as Keira or Sennar. Historically determined memory, born of hatred towards the inhabitants of the arabized North for their kidnapping and trading of their sons and daughters, has been kept alive till the present day ${ }^{7}$. At that period of time there were also territorial boundaries, very similar to the present ones. Equatoria and the Province of Bahr al-Ghazal were conquered and annexed. It is also the time when in Sudan, after a long interval of absence, lasting from the $16^{\text {th }}$ century, Christians appeared again. They were Jesuit missionaries and Egyptian and Greek Copts. During this time, the Sudan became open to the international trade. It is sad to state that the main "export of goods" unfortunately consisted in slaves. Some positive aspects of this period in Sudanese history, were the efforts to create a single state administration for the entire country, with ethnical variety. It is essential to notice that many

6 See A. Cedro, Zapomniane klasztory. Odkrywanie chrześcijańskiego dziedzictwa średniowiecznej Nubii, in: Sudan - bogactwo kultur $i$ wewnętrzne napięcia, ed. W. Cisło, J. Różański, M. Ząbek, Warszawa, 2012, p. 95-96.

7 See A. H. M. Makki, Sudan: The Christian Design, Khartoum 1989, p. 18-21. 
efforts were made to create an educational system. Nonetheless, the governors, mainly of Egyptian descent, have gone down in history as cruel and ruthless collectors of taxes and contributions ${ }^{8}$.

The era of Turkiyah was followed by the period called Mahdiji in 1881-1899. There followed the further assuming of influence by the British, taken as an advantage by one of the religious leaders, Muhammad Ahmad Ibn Abd Allah to organize rebellion. Under his rule very strict ascetic laws for the lives of the people were introduced. Only the joint intervention of the Egyptian and the British army brought this revolt to an end. This became an excuse for the British to expand their sphere of influence. They even declared their claim to govern Sudan themselves; however, the pressure of European powers stopped their ambitious plans and, together with Egypt, created the condominium that was able to last for more than 50 years. The reasons for such a clear division of Sudan into North and South are placed by many historians in this period ${ }^{9}$. The answer can be found in the report that happened to reach London: "The South is the biggest problem in this country. Educated Sudanese people treat the South in a way that Egypt is treating them. The South, however, very much like the northern part of Sudan, for Egypt is the source of cheap labour and servitude. The South should not be united with the Arabic North. Humanly thinking the South belongs to Black Africa"10.

For the British, who earlier did not show an interest in the South, because they looked at it as an unusable region, and due to the earlier mentioned difficulties, expensive governance, during the condominium period was gaining more value. What brought about a change in the British approach to the South, was the Nile River and the possibility of its use. Despite this change in the approach, they needed almost 20 years to take control over this region, at the same time having guaranteed autonomy to the local tribal leaders. What caused mutual animosities was the way of dealing with the governed territories. The South, taken as unstable territory, was under special control and the only thing, in taking care of it, was to maintain peace, neglecting any kind of care for the economic development and education. In order to get rid of the care for education, the Catholic missions were allowed to expand, because they had always emphasized this sphere of human life. Historical

\footnotetext{
8 See M. Zabek, Historia Sudanu, p. 15 n.

9 See M. Zabek, Historia Sudanu, p. 131-133.

${ }^{10}$ Quoted after: J. Oduho, W. Deng, The problem of the Southern Sudan, London 1965, p. 17.
} 
facts justified this encouragement towards the work of missionaries. Their presence was supported by the fact that Christians were in Sudan earlier than Muslims. Missionary activity was concentrated mainly in the South, though missionary work permits were granted to work also in Northern areas ${ }^{11}$. Father Olivier Claude Allison, later made a bishop, wrote in his reports: "Signs of the growth of Islam in the South are already visible: mosques of impressive size are built by money granted by the Egyptian government, and in the city centers, Islamic schools are build"12.

Important, from the point of view of mutual Christian-Muslim relationships, appears the bishop's statement on the Christian presence in the North. "Thanks God there is another side of the coin. There already exist Christian clubs in Khartoum and Omdurman for the boys from the South working in the North. They have even specially arranged Holy Mass in the Cathedral in Khartoum. There is also some progress in planning to raise a Christian center in Omdurman that we realize jointly with the Protestant mission. There is a significant and much encouraging sign: the Municipal Office in Omdurman - an entirely Muslim body - consented to grant appropriate buildings for the Christian Center. As the visibility of Islam is growing in the South, so the Catholic Church must advance in the North ${ }^{13}$.

The year 1922 brought about some essential changes in the EgyptianBritish relationship towards the Sudan. The British strengthened their domination over the condominium, implementing, at the same time, a great deal of independence for the local communities in Sudan. This change was preconditioned by the concerns of conveyance of independent ideas from Egypt $^{14}$. Those concerns, preceding the spread of independent tendencies made the British implement, for Sudan, two strategies of governance, one for the North and another for the South. Because of this, in 1922 a so called Closed District made of three provinces was created: Bahr Al-Ghazal, Equatoria and the Upper Nile. Inhabitants of Northern Sudan (Muslims) could get there only with the special permit issued by the Governor of the Province or the Civil Secretary. This restriction was aimed at preventing further islamization of

${ }^{11}$ A.B. Sawant, Ethic Conflict in Sudan in Historical Perspective, "International Studies" (1998), no 35(3), p. 345-348.

${ }^{12}$ Reports and statements on Church affairs in the Sudan, The Sudan yesterday and tomorrow, O. C. Allison, 1940, DAD.803/13/1-5, Sudan Archives.

${ }^{13}$ Ibidem, p. 20.

${ }^{14}$ Ibidem, 22/176. 
the country and simultaneously to encouragement the Christian missionaries to expand their missionary work in the South of Sudan. As a result, these actions were strengthening ethnical groups living in the South and as the British had intended, were to create a specific barrier for the islamization and arabization of the region. This, however, led to accusations both from the side of the Northern and Southern populations that the British authorities were attempting to cause disagreements between the Sudanese people ${ }^{15}$. The effect of this ruling model was the fact that it failed to stop complete islamization of the South and led to the economical degradation of the region, because of the necessity to obtain entry permits by the inhabitants of the North. The end of the Second World War brought about a change in the British policy towards the South, imposed by force by the Northern population. A new British policy towards its former colonies implied equal autonomy of the North and South. Despite the wide disparities within the British administration regarding the view on the Sudan as one entity, at the Juba Conference in 1947 the Southern people stood for the unity of Sudan ${ }^{16}$. A quoted author gives an account of a very interesting attitude of the Christian missionaries, who, in his opinion, from the beginning were pointing out some threats. As the most important conviction among them, they were indicating the lack of sufficient foundations for a united state. On the basis of current experiences, they felt very concerned about Islam becoming a state religion and feared obstructions in the running of their missions as well as that the educational system would be dominated by the koranic law. History proved that their fears had been reasonable because all of these fears became fact ${ }^{17}$.

In the context, presented by us, regarding the causes for the split of Sudan into the North and the South, the statement of John Winder who was the Governor of the Upper Nile Province appears extremely important. In one of his letters he wrote: "I am trying to write a letter to the Civil Secretary with regard to the unification of Southern and Northern Sudan. As a matter of fact, it has never been taken as a decision that it should come to this unification[..]. I reckon that the main issue is religion. In the course of the years we have been encouraging Christian missions to work in the South and discouraging them to learn Arabic language as a requirement. In state schools, however, Arabic

\footnotetext{
${ }^{15}$ M. Ząbek, Historia Sudanu, p. 130.

16 A. B. Sawant, Ethnic Conflict in Sudan..., p. 350.

17 A. B. Sawant, Ethnic Conflict in Sudan...
} 
language was taught. Simultaneously we have encouraged the promotion of Islam through the creation of Closed Districts ${ }^{18}$. According to his opinion, the people of Southern Sudan should suggest to the Arabs from the North, that unification of Sudan could take place only on the economic and political basis, and not on the cultural and religious one. Despite various opinions within the British administration as to whether Sudan should be independent, the proposal that the Sudanese should govern the country themselves was outweighed. The proof for this pattern of thinking is the letter of J. W. Robertson written to the Bishop of Khartoum in March 1948. It contains a specific summary of the British policy towards the South. In the context of the subject considered by us, we quote below some points made in that letter:

a. "I do not know, how long the British will be able to administer Sudan, keeping it away from the Egyptian and maintaining their influence in the North;

b. The longer we stay the better for Sudan and for the Southern Sudan;

c. The longer we will cooperate with the Northern Sudan the better for the Southern people, they will have more time to learn to stand on their own feet...[...];

d. The conclusion is such that we have to accelerate as much as possible the educational process and development of the South so that when, in the future, we are no longer there, the Southern people could exist independently.

As missions are concerned, I cannot see how the government could take care of them and support them. Christianity needs to rely on its own values[...] and to overcome Islam without governmental support. I reckon that the Church will be stronger, when it will fight and is not dependent on the support of the government"19.

In that above-quoted "Sudan Archive" we find also some views of people from the South that confirm the fears of the British officials. One of them is the letter of the Bari chief from November 1952. It says inter alia:

"We are grateful to the missionaries, who have come to the South with the support of the British government and begun the process of education that is

${ }^{18}$ Letter from Winder to W.H. Haslam setting out his views on the future of the southern Sudan, 1946 Oct 30- 1947 Feb 19, SAD.541/12/6-9, Sudan Archive.

${ }^{19}$ Confidential letter from Sudan Government Civil Secretary's Department. Civil Secretary Officer J.W. Robertson, 22 March 1948, SAD. 809/1/6, Sudan Archive. 
still only at its initial stage. It is still way too early for all parts that the Southern Sudan could wisely decide about its own future. However, if the North exercises its pressure, this would be to the benefit of the North, not to the South, and when the British government allows this, we would ask politicians to visit each part of Southern Sudan in order to have a full picture of the South.

A crippled man is not able to compete with another man who is not crippled. A blind one does not know how beautiful is the world.

If my older brother would wish that our father die in order to inherit his position, we should say with a loud voice that it is not the time for our father to die, because we are still too young. We want that the British deal with the administration of the country till the time, when we are able to decide about our lot" ${ }^{20}$.

The Legislative Assembly that took place in 1952 approved the two-house Parliament and Sudan government, leaving to the British the responsibility of foreign affairs and the administration of the South. In 1953, when in Egypt a coup took place, the British-Egyptian agreement was terminated. In the year 1954, the first session of the Sudanese Parliament was held; an election had taken place a year before. A majority was won by those who were in favour of a union with Egypt and of the Sudan's independence. In the 97-seat Parliament the representatives of the South received only 9 seats $^{21}$. This date can be considered as the beginning of the intensive conflicts along the line: North-South. The Arabs began to replace the British in the administration, in factories and in other lucrative positions in the South. As a summary of those events, the statement from the letter of Jack E. C. Mackrell to G. W. Bell bears important evidence of the state of affairs: "Now the choice between our sensitivity to the right relationship with the Sudanese from the North and the risk of bloodshed among simple folk, who are still counting on us, seems to be obvious" 22 .

On January 1, in the year 1956, Sudan declared its independence despite the ongoing civil war. The cause of it was the lack of proper representation of the South in the government and the lack of respect of the cultural and

\footnotetext{
${ }^{20}$ Letter from Bari chief, Semi-official correspondence to Bell, 2 Nov 1952, SAD. 696/8/81, Sudan Archive.

${ }^{21}$ M. Ząbek, Historia Sudanu, p. 123.

${ }^{22}$ Letter from Jack E. C. Mackrell Esq. To G. W. Bell, Wau 10 May 1954, SAD.696/11/62-64, Sudan Archive.
} 
religious distinctiveness of the South. The fears of the people from the South turned out to be true that the joining of two administrative units so distinct in culture and religion could not yield good effects. The South, thanks to the support of the British for a long period of time, had been undergoing a dynamic evangelization process, whereas the North was almost 100 per cent Muslim. Taking into consideration the history of Sudan, in which a great role was played by the slave trade, we can imagine the situation of the people from the South who were considered by the inhabitants of the North as "infidel". The position of "an infidel" was not ultimately different from the status of a slave. Also the most modern history, namely, till the year 2011, proves this pitiable status. Many Southern Sudanese - home refugees - were treated by the inhabitants of the North as slaves ${ }^{23}$.

Since 1965 as many as about 50,000 Arabs have been moved to the South, finding employment in the administration of that region. It happened that very often they took as their wives Christian women or of the animist belief. Children born of those marriages were sent to the North where they were educated and indoctrinated in the spirit of Islam. Later on they came back to claim the land of their mothers ${ }^{24}$.

According to the opinions of some experts on the subject, there can be two distinct matters that have contributed to the split of the North and the South. Those were: education and religion. In a united state those issues were settled in favour of the North. After the declaration of independence on January 1, 1954 all the Christian private schools in the South were closed down. There remained only state schools with Arabic as the language of instruction and with the upbringing model based on the Koran teaching. A distinct educational system modelled on that in the North was imposed. This caused enormous problems. The South did not have a sufficient amount of class books in Arabic, nor teachers who knew the language. It became necessary to bring a great number of teachers from the North. Their chief mission was to be advocates of the idea of a united Sudan and to promote Islam and Arabic culture. As a result, the pupils having completed such schooling were unable to speak Arabic correctly while they could well recite the verses of the Koran that became a principal teaching subject. Disparities in the access to education can

${ }^{23}$ See W. Cisło, Raport Prześladowani i Zapomniani 2007-2008, Warszawa 2008, p. 140-145.

${ }^{24}$ M. Kurcz, Sudan: Koniec najdluższej wojny w dziejach postkolonialnej Afryki?, „Arcana” (2005) Nr 63. 
best be shown through figures: in 1960, in the South, there was not a single tertiary institution, whereas in the North there were four universities. The South had 18 primary schools comprising one for girls, while in the North in comparison, there were 200 schools for boys and 55 for girls. By contrast, from among 1,200 students at the university in Khartoum only 60 were from the South ${ }^{25}$.

Apart from education, the issue of religion was also dividing the Sudan. Having obtained independence the fears of the British administration and Christian missionaries became a reality: Islam was made the state religion. The only way to attain an occupational and social status was to convert to Islam. Frequently it was done according to the rule of an already accomplished fact or by pressure ${ }^{26}$.

This was accompanied by the expulsion of Christian missionaries, or at best, their activities were considerably restricted. The government took over the entire infrastructure of the missions, beginning with hospitals, nursing homes and churches. A major symbol of changes was a shift of a day-off from Sunday to Friday that occurred in 1960. In 1962, "the Missionary Society Act" was adopted: this was a counter-missionary ruling, for all missionary activities without the government's permit were outlawed ${ }^{27}$.

The other forms of repression included a refusal to grant visa extension for missionaries and also depriving them of the positions they were currently holding. In the year 1964 as many as 200 Catholic missionaries as well as a numerous group of missionaries from the Anglican Church and a few missionaries from African countries were expelled from Sudan ${ }^{28}$.

The brutal ways of the governance by the Khartoum authorities towards the people of the South only has made the existing historically pre-conditioned divisions deeper and perpetuated them. It is easy to come to understand them when we take into consideration that the method of the enforcement of power in the South was to set houses alight, carry out public executions and imprison people, this shows how Arabs can deal with the "infidel".

25 J. Oduho, W. Deng, The problem of the Southern Sudan, London 1963, p. 46-47.

${ }^{26}$ More on this matter: J. Oduho, W. Deng, The problem of the Southern Sudan, London 1963.

27 J. Oduho, W. Deng, The problem of the Southern Sudan, London 1963, p. 57.

${ }^{28}$ Memorandum for members of the goodwill of the All Africa Conference of Churches concerning the Sudan, 1966, SAD.803/13/13-17c. Sudan Archive. 


\section{Violation of fundamental human rights a reason for perpetuation of the split of Sudan at the turn of $20^{\text {th }}$ century}

Human rights belong to the foundations of democracy. Modern democratic systems were preceded by the development of the idea and followed by the codification and definition of human rights. In the course of European history the violation of human rights has led always to the limitation or destruction of developed democratic rules. It applies evenly to the West (Hitler and his system) as well as to the East (Stalin).

Human rights have been usually systematized with categories. In the literature of the subject we come across a distinction on fundamental, civil and political rights.

What in European countries has been already thoroughly discussed and commonly accepted, is still under the formation processes in African countries. In addition to this, there is a vast distinction in the category of human rights between the European culture based on the Christian heritage and, on the other hand, African countries as well as others, where the system of values is based on the Koran ${ }^{29}$. In the light of the Koran an individual should totally be subordinated to God and to the community of the believers and in no way should be allowed to break away from this structure. Here we can see an approach to the status of an individual as a very distinct from the liberal Euro-American doctrine. This approach embraces an entire sphere of life. It applies equally to the economic, political rights as well as to the principal rule of non-discrimination of an individual (e.g. the status of the adherents of different religions, of women, sexual minorities). There exist, though, attempts "to islamize human rights". As an example one can mention the Universal Islamic Human Rights Declaration proclaimed by the UNESCO in 1981 by the Islamic Council for Europe. Another example is the Charter on Human Rights and Peoples in the Arab World drawn up by the Arab experts in Syracuse in 1986. They showed a certain attempt at unification with what the West has worked out on the grounds of long discussion. Insurmountable discrepancies are the result of the fact, that in many Muslim countries a decisive voice with regard to the law or constitutional articles belongs to the Muslim clerics who do not have a single legal interpretation centre. Human rights are interpreted

\footnotetext{
${ }^{29}$ More on this topic: A. M. Hamed, Problematyka praw człowieka w Sudanie. Afrykański Wygnaniec. Tożsamość a prawa człowieka, ed. J. Mantel-Miećko, Warszawa 1999, p. 244-270.
} 
in a manner which depends on whether a cleric is a member of a more or less radical branch of Islam.

There are great differences in the perception of human rights by the people of the European culture area and the area of Islamic culture. The author's conviction with regard to what had the strongest impact on the call for a referendum and what finally sealed the split of Sudan into the North and the South, is that there were religious issues, as well as the arrogance of the Khartoum authorities in the violation of fundamental human rights. In the second part of the article only some of the points regarded by the author as most essential will be described: religious fundamentalism and Sharia law.

The end of the $20^{\text {th }}$ century showed that religious fundamentalism is a phenomenon of political character and global scope. Its origins are derived from the politicized American Protestantism. In the literature of the subject we come across a term: "fundamentalisms", for they differ in the time they came into existence, in the forms of their impact, the latter difference being caused by the religious community they originate from ${ }^{30}$.

Muslim fundamentalists do not only condemn democracy, and what follows, including religious tolerance, but also reject a secular nation state, referring to an argument that it was a tool created by the West. Instead of democracy and secular nation state they propose the "Muslim solution". Frequently it contains a very dangerously sounding word: one nation, one religion, one state. Regrettably we cannot avoid here associations to the ideology of Hitler.

In the context of Sudan, one of the biggest country in Africa, with a population of over 37 million, comprised of 70 per cent Muslim believers, 14 per cent of Christians, and 12 per cent of animists ${ }^{31}$, it is of great importance for the correct perception of fundamentalism to be familiar with the history of this country as presented earlier. The fundamentalist movement in Sudan has been present since the 1950s and was imported by students who accomplished their education in Egypt where they had come across with the ideas of the Muslim Brotherhood. In 1959-1964 this movement was strengthened. During the parliamentary elections in 1964 two of its representatives won seats in Parliament. Its formal representation was a Party called the Islamic Charter

\footnotetext{
${ }^{30}$ M. Riesebrodt, Fundamentalismus als patriarchalische Protestbewegung, Tübingen 1990, chapter 2 .

${ }^{31}$ W. Cisło, Raport Prześladowani i Zapomniani 2007-2008, Warszawa 2008, p. 140-145.
} 
Front. Sudanese fundamentalism like many other Muslim fundamentalisms is being termed "a return to the religion of the ancestors" 32 . In this radical form it is not only a return to the tradition of the ancestors and to the following of the sacred book of Koran. What caused the biggest problems was coming from the original perception of Islam as a joining factor of what is earthly and spiritual in human life. A practical effect of such an approach was the politicization of religion that automatically resulted in the revolt against the West. Christianity in Sudan was but an element of the western culture.

These fundamentalist activities have made Sudan, in many respects, a totalitarian state. Over many decades what we have been dealing with is a single party oppressive system, bloody fighting against the opposition and the believers of other religions. The impact of the ideology on politics is visible not only in fighting against all other currents of ideas different from Islam. There have also been fights against less radical currents in Islam itself. A matter of concern has become the increased role of Islamic militia and the diminished position of the army.

As a consequence of such an attitude is the issue of the islamization of Sudan. This process began in 1956 at the time of independence. Already the first Sudanese government set up a special committee whose task was to search for any contradictions to the Koran in contemporary state law. This committee's responsibility was to prepare regulations that are in compliance with the Koran and to put them in place of the English laws. A result of this was the Criminal Law Act passed in 1991, for instance, penalizing an armed assault (art. 168/1) with death penalty, crucifixion or amputation of a right hand and left foot, apostasy (art. 126) with the death penalty if an accused persists in apostasy. This regulation is very dangerous because its free interpretation could be directed against Christians and the missionaries working in the north of Sudan. This is only a small example regarding to what extent the violation of freedom of conscience and religion goes. This violation consists in the application by the state of numerous ways to discourage other religions than Islam or to compel conversion to Islam. Acquisition of land, for instance, in some areas was reserved only for the Muslims. Similar discrimination takes place also in job application. In the context of the equality of religions and religious freedom, article 126 of the criminal law (1990) is of interest. It states: 1) "An apostate (ridda): any Muslim who advocates the rejection of Islamic

\footnotetext{
${ }^{32}$ Salaf - ancestor. Hence a name: Salifijja.
} 
beliefs or publicly renounces it is said to commit the offence of apostasy; 2) Whoever commits apostasy shall be asked to repent within a period decided by the court and if he insisted on his apostasy and was not a new convert he shall be punished to death; 3) Punishment for apostasy lapses if the apostate refrained from apostasy before the execution". The Sudanese government is justifying such a radical attitude to apostasy with the claim that apostasy is usually accompanied by other offences causing harm to society or the state. It is strongly necessary to be underlined, that article 126 stands clearly in contradiction with resolutions of international law. What is interesting is that this regulation can be applied not only to the persons belonging to the religious minorities but in extreme cases also to the believers of Islam with unorthodox views ${ }^{33}$.

Despite the fact that the government officially declares respect for all religions, in reality it regards only Islam. We can give as an example a case of a priest who baptized three Muslim women. He was arrested along with them. Other forms of repression towards the believers of other religions than Islam are marriage restrictions. A Muslim is permitted to marry a woman of another religion but the opposite situation is not allowed. The only exception is a case when a man converts to Islam. These restrictions apply to the Nubians as well as the tribes inhabiting the South. Non-Muslims are allowed to adopt only non-Muslim children, but Muslims enjoy freedom in this matter. In case of a lack of information with regard to the children whether they come from the families of other religions than Islam or were abandoned by their parents, they are automatically regarded as believers of Islam. A similar form of islamization forced children in refugee camps to read the Koran. Numerous similar examples during the long-lasting civil wars can be quoted ${ }^{34}$. It is interesting to note that there is no rule that would restrict conversion to Islam. In the North, for over 30 years (from 1975 up to 2005) no permission was granted to build a Christian church. As it is pretty easy to guess, to raise a mosque does not require any permit.

A very effective method of making converts to Islam was that towards prisoners and slaves in the labour camps. As one of the organizations monitoring the situation of non-Muslims in Sudan - Christianity Solidarity International

33 A. M. Hamed, Problematyka praw człowieka w Sudanie, in: Afrykański Wygnaniec. Tożsamość a prawa człowieka, ed. J. Mantel-Miećko, Warszawa 1999, p. 262.

${ }^{34}$ W. Cisło, Raport Prześladowani i Zapomniani 2007-2008, Warszawa 2008. 
relates: in the years before the referendum certain dramatic situations took place in labour camps and in prisons. According to its reports, almost all prisoners were subjected to torture and mental and physical assault. 86 per cent of them were "converted" by force to Islam, 55 per cent of them witnessed the execution of their fellow-prisoners, 99 per cent of them were regularly hit, and 99 per cent of them were assaulted on racial religious grounds ${ }^{35}$. What equally intensified hatred was taking individuals into captivity and placing them in labour camps. This happened to men as well as women and children. As it is reported by the International Covenant on Civil and political Rights (ICCPR), this situation concerned a huge number of persons and met with no reaction whatsoever from the side of the government. In the summer of 1996, the government in Khartoum announced that it was deeply taken aback by the news about the widespread slavery procedures in Sudan. The resolution of the General Assembly of the UN from 1995 established the Investigation Committee on Allegations of Enforced or Involuntary Disappearances and Reported Cases of Slavery. In the Nuba Mountains many camps were discovered wherein the Nubian were forced into slave labour and also sexually exploited. According to the deepest convictions of international observers those labour camps can be termed concentration camps. The author of this article was given to see with his own eyes similar situations in camps around Khartoum in December 2011. Many situations like these have been noted by international observers and persons dealing with the respect of human rights in the Sudan itself as well as in neighbouring countries. Numerous camps of this type have been found also in Uganda. Another matter regarding Christian-Muslim relationships is the forcing of people to convert to Islam in return for aid offer. The main purpose of this type of procedure is the will to create a uniform state with regard to religion. Unfortunately, those were not isolated proceedings, whereof we have the knowledge from anonymous verbal statements of the people working in the camps in Khartoum and in $\mathrm{Wau}^{36}$.

The lack of action which the international community can be mostly blamed for in this long lasting conflict is the fate of children. For example, a serious fact is the enrollment of 17,000 boys of the age of $12-15$ by the SPLM (Sudan

\footnotetext{
35 W. Cisło, Raport Prześladowani i Zapomniani 2007-2008, Warszawa 2008, p. 143.

${ }^{36}$ Statements of those people who have to remain anonymous, because even today they are in danger of retaliation for passing on information to people outside Sudan.
} 
People's Liberation Movement) and directed for military training. Often the "training methods" used were hitting, intimidations and other cruel methods. The government behaved in a similar way. Children taken from the street or from the refugee camps were placed in primitive conditions, where often there were not enough basic means of hygiene and food. The only things they were never lacking were lessons on the Koran. Non-Muslims were forced to convert to Islam. The authorities in Khartoum were organizing round-ups at night in places where the children from refugee camps used to sleep, in order to fill up training camps. Supervision over those camps was controlled by the Islamic Non-Governmental Organization ${ }^{37}$.

The fate of children, who were in the regions of ongoing military combats, was particularly cruel. The majority of them witnessed the mutilation, killing and raping of people. Many of them lost their relatives. Many of them became soldiers by force. The fate of children and women equally is the fault of all parts involved in the Sudan conflict before the referendum. Taking into consideration the aversion to slavery due to the fact that Sudan used to be a terrain for the acquisition of slaves, it is no wonder that contemporary slavery - in particular that of children - has caused an animosity between the North and the South of the Sudan.

The other issue is the situation of women in the country in the civil wartorn-areas. The most tragic of them is the trading of women from the South for domestic service in the North, what effectively can be described as slavery. Although theoretically the Muslim women have the ensured right to intact property and may inherit their parents, in practice these rights are not always respected. The situation of non-Muslim women is far worse. After 1989, regulations were introduced causing serious unrest as the women's situation is concerned. Another infringement of the rights of women is their restriction to move freely around the country. They can do so only in the presence of their husband or of another family member. Another grave discomfort is the requirement for all women to dress themselves according to the Koran rules. As an example, to confirm these islamistic tendencies, we mention the presidential decree of May 2006 regarding a thousand Christian women arrested under the allegation of violation of Sharia laws. They were released only in August 2007.

${ }^{37}$ M. Madej, Sudan, in: Problematyka prawa czlowieka w Sudanie. Afrykański Wygnaniec. Tożsamość a prawa człowieka, ed. J. Mantel-Miećko, Warszawa 1999, p. 236. 


\section{Bibliography}

Archiwum Sudańskie (The Sudan Archive, Durham Univeristy Library, Archives and Special Collections), http://reed.dur.ac.uk/xtf/view?docId=ead/sad/sudan.xml (06.02.2014).

Cisło W., Raport Prześladowani i Zapomniani 2007-2008, Warszawa 2008.

Cisło W., Różański J., Ząbek M., Bilad as-Sudan kultury i migracje, Warszawa 2013.

Cisło W., Różański J., Ząbek M., Sudan - bogactwo kultur i wewnętrzne napięcia, Warszawa 2012.

Makki A. H. M., Sudan: The Christian Design, Khartoum 1989.

Mantel-Miećko J., Afrykański Wygnaniec. Tożsamość a prawa człowieka, Warszawa 1999.

Mantel - Niećko J., Ząbek M., Róg Afryki. Historia i współczesność, Warszawa 1999.

Oduho J., Deng W., The problem of the Southern Sudan, London 1965.

Vantini G, Oriental Sources concerning Nubia, Bologna 1975. 